\title{
Urinary Advanced Oxidation Protein Product: A Potential Oxidative Damage Marker for Cancer

\author{
S Chandramathi ${ }^{1}$, K Suresh ${ }^{2}$, ZB Anita ${ }^{3}$, UR Kuppusamy ${ }^{4}$
}

\begin{abstract}
Objective: Oxidative stress has been implicated in the pathophysiology of various life threatening diseases namely cancer, cardiovascular disease and diabetes. This study aims to compare the severity of oxidative damage in cancer and some factors that may influence the levels of urinary oxidative biomarkers. The factors were sample collection period, cancer stages and lifestyle disease conditions (which are known to be associated with oxidative stress) such as diabetes with and without hypertension.

Methods: The effects of the above mentioned factors on the levels of urinary advanced oxidation protein product (AOPP) and other oxidative indices such as hydrogen peroxide $\left(\mathrm{H}_{2} \mathrm{O}_{2}\right)$, malondialdehyde (MDA) and ferric-reducing antioxidant power (FRAP) were evaluated according to well-established methods.

Results: The period of sample collection did not show any significant difference in the parameters tested. The levels of oxidative stress in breast and colorectal cancer patients that generally increased with the cancer stages showed that cancer progression correlates with high oxidative damage. Comparison between diabetes with and without hypertension did not give any significant difference in the parameters tested. Among all the four oxidative indices, the level of AOPP in breast, colorectal and other types of cancers were significantly higher compared to diabetes with or without hypertension.

Conclusions: The oxidative damage to protein is significantly higher in cancer and may potentially serve as a non-invasive oxidative biomarker for this disease.
\end{abstract}

Keywords: Cancer, diabetes, free radicals, non-invasive, oxidative damage

\section{Productos Proteicos de la Oxidación Urinaria Avanzada: un Potencial Marcador de daño Oxidativo para el Cáncer}

\author{
S Chandramathi ${ }^{1}$, K Suresh ${ }^{2}$, ZB Anita ${ }^{3}$, UR Kuppusamy ${ }^{4}$
}

\begin{abstract}
RESUMEN
Objetivo: El estrés oxidativo ha estado implicado en la fisiopatología de varias enfermedades que amenazan la vida, tales como el cáncer, las enfermedades cardiovasculares y la diabetes. Este estudio persigue comparar la severidad del daño oxidativo en el cáncer y algunos factores que pueden influir en los niveles de los biomarcadores oxidativos urinarias. Los factores fueron el periodo de recolección de la muestra, las etapas del cáncer y las condiciones de las enfermedades relacionadas con el estilo de vida (de las que se sabe que están asociadas con el estrés oxidativo), tales como la diabetes con ó sin hipertensión.

Métodos: Los efectos de los factores anteriormente mencionados sobre los niveles de los productos proteicos de la oxidación avanzada (AOPP) urinaria y otros índices oxidativos tales como el peróxido de hidrógeno $\left(\mathrm{H}_{2} \mathrm{O}_{2}\right)$, el malondialdehido (MDA), y el poder antioxidante de reducción férrico (FRAP) fueron evaluados según métodos bien establecidos.

Resultados: El periodo de recogida de la muestra no demostró ninguna diferencia significativa en los parámetros de prueba. Los niveles de estrés oxidativo en los pacientes con cáncer de mama y colorrectal, que generalmente aumentaron con las etapas del cáncer, demostraron que la progresión del cáncer se correlaciona con un elevado daño oxidativo. La comparación entre la diabetes con hipertensión y sin hipertensión no arrojó ninguna diferencia significativa en los parámetros sometidos a prueba. Entre todos
\end{abstract}

From: ${ }^{1}$ Department of Medical Microbiology, ${ }^{2}$ Department of Parasitology, ${ }^{3}$ Unit of Clinical Oncology and ${ }^{4}$ Department of Biomedical Science, Faculty of Medicine, University Malaya, 50603 Kuala Lumpur.
Correspondence: Professor UR Kuppusamy, Department of Molecular Medicine, Faculty of Medicine, University of Malaya, 50603 Kuala Lumpur. Fax: 603-79676600,e-mail: umah@um.du.my 
los cuatro índices oxidativos, los niveles de AOPP en los cánceres de mama, los colorrectales, y otros tipos de cánceres, fueron significativamente más altos en comparación con los de la diabetes con o sin hipertensión.

Conclusiones: El daño oxidativo a las proteínas es significativamente mayor en el cáncer, y puede servir potencialmente como un biomarcador oxidativo no invasivo para esta enfermedad.

Palabras claves: Cáncer, diabetes, radicales libres, daño oxidativo, no invasivo

West Indian Med J 2016; 65 (3): 506

\section{INTRODUCTION}

Cancer is known to be the leading cause of death worldwide. In 2012 alone, cancer had claimed 8.2 million lives worldwide. More than $70 \%$ of these deaths had occurred in developing countries. According to the World Health Organization (WHO), the global annual cancer cases are expected to rise from 14 million in 2012 to 22 million in the next 20 years (1). In Malaysia, breast and colorectal cancers are the most prevalent among women and men, respectively. In the year 2007, breast and colorectal cancer incidences in Malaysia were 3292 and 2246, respectively (2). The mortality rate of cancers can be reduced with successful early detection.

Oxidative stress is a condition that describes equilibrium disorder in the status of free radical-antioxidant productions in favour of free radicals namely reactive oxygen species [ROS] (3). Reactive oxygen species such as superoxide radical $\left(\mathrm{O}_{2} \bullet\right)$ and hydroxyl radical $(\bullet \mathrm{OH})$ can stimulate oxidative damage to lipids, proteins and nucleic acids. Oxidative stress has been implicated in the aetiology of cancer and evidence show that DNA mutation, caused by oxidative damage is one of the initial steps of carcinogenesis (4).

Numerous studies have attempted to assess oxidative stress level in cancer patients utilizing both invasive (eg: serum, erythrocyte and tumour tissues) and non-invasive samples [eg: urine and saliva] (5-9). Some of the oxidative damage markers used in these studies include advanced glycation end-products (AGEs), malondialdehyde (MDA), hydrogen peroxide $\left(\mathrm{H}_{2} \mathrm{O}_{2}\right)$ and uric acid. Our past study showed that oxidative damage indices especially advanced oxidation protein product (AOPP) were significantly increased in the urine samples of breast and colorectal cancer patients (10). The level of urinary ferric reducing antioxidant power (FRAP) in these patients was also lower compared to the healthy individuals, implicating that urinary oxidative indices may serve as potential non-invasive oxidative markers in cancer.

Generally, urinary metabolites are considered as good indicators of damaged or oxidized products excreted from the entire body over a broad span of time (11). However, there are other factors that may affect the levels of oxidative damage products excreted in the urine that should also be taken into consideration. These factors include time of sample collection and cancer stages. Therefore, the main objective of the present study was to assess the effect of the above mentioned factors on the levels of urinary oxidative damage indices namely AOPP, $\mathrm{H}_{2} \mathrm{O}_{2}$, MDA and FRAP. In order to assess the potential use of a non-invasive oxidative marker in cancer, a comparison was also made with other disease conditions such as diabetes with and without hypertension in which oxidative stress is also commonly implicated.

\section{SUBJECTS AND METHODS \\ Determination of sample collection period}

A total of 30 age-matched volunteers comprising employees and students from the Medical Faculty of University Malaya were recruited for this experiment. Urine samples were collected periodically, in the morning (before breakfast), two hours after breakfast and two hours after lunch. No diet restrictions were imposed on the volunteers. All the subjects were on a normal balanced diet (determined based on questionnaires). In the present study collection periods were not extended to night. The study was approved by the Ethics Committee of University Malaya Medical Centre (UMMC). Informed consent was obtained from all subjects prior to the sample collection.

\section{Subjects for cancer stages}

In this experiment, 46 breast cancer and 28 colorectal cancer patients attending the Oncology Clinic, UMMC were recruited. Urine sample was collected from each patient who had not begun chemotherapy. With reference to the medical information, these patients were categorized according to different cancer stages. Breast cancer patients attending UMMC were mostly at cancer stages I, II and III whereas colorectal cancer patients were generally at stages II, III and IV.

\section{Cancer and diabetic (with and without hypertension) subjects}

Fresh urine samples (first morning specimen) were collected from 140 randomly selected Type 2 diabetic patients attending the Diabetic Clinic at UMMC. Diabetic patients with renal failure or nephropathic conditions were excluded from this study. The diabetic patients recruited were subdivided into hypertensive $(\mathrm{n}=96)$ and non-hypertensive $(\mathrm{n}=44)$ groups and their levels of oxidative indices were compared with breast cancer $(n=95),(C R C)$ colorectal cancer or CRC $(n=45)$, noncommon or other types of cancers namely stomach, nasopharyngeal, lung and prostate cancer $(n=64)$ patients as well as control subjects $(n=85)$. All of the cancer subjects had undergone surgery and most of them were receiving chemotherapy at the Oncology Clinic, UMMC of Kuala Lumpur, 
Malaysia. The control subjects consisted of volunteers from the Klang Valley, Malaysia.

\section{Biochemical analysis}

The urine samples were centrifuged at $2000 \mathrm{~g}$ for 10 minutes and the supernatant was collected and stored at $-70{ }^{\circ} \mathrm{C}$ until analysis. The assays for four oxidative indices namely AOPP, $\mathrm{H}_{2} \mathrm{O}_{2}$, MDA and FRAP were carried out within 24 hours upon sample collection. Advanced oxidation protein product was measured according to the method of Witko-Sarsat et al (12). Urinary $\mathrm{H}_{2} \mathrm{O}_{2}$ was measured using ferrous ion oxidative xylenol orange version-2 (FOX-2) method by Banerjee et al (8). Lipid peroxidation in the urine was determined by measuring MDA according to the method of Kuppusamy et al (13). Whereas, FRAP assay was carried out based on the method by Benzie and Strain (14).

Data were analysed using SPSS for Windows computing programme (Version 17.0). All data were expressed as mean \pm SEM and the significance of differences between the patient groups and control were analysed using Student's $t$-test. The significant differences of parameters tested among the disease groups (eg: various cancer types and diabetes) and cancer stages were assessed using one-way analysis of variance (ANOVA) analysis.

\section{RESULTS}

Table 1 depicts the demographic data of the subjects recruited for the comparison among normal, cancer and diabetic groups.
Table 2 shows the levels of urinary oxidative indices according to three different sample collection periods. The comparison between different collection periods did not show any significant differences for all parameters measured.

Table 2: Urinary oxidative indices according to different time of sample collections

\begin{tabular}{lccr}
\hline Parameters & Before breakfast & \multicolumn{1}{c}{ Two hours } \\
after breakfast & \multicolumn{1}{c}{$\begin{array}{c}\text { Two hours } \\
\text { after lunch }\end{array}$} \\
\hline $\mathrm{AOPP}(\mu \mathrm{mol} / \mathrm{L})$ & $88.77 \pm 3.48$ & $90.42 \pm 3.51$ & $81.62 \pm 3.69$ \\
$\mathrm{H}_{2} \mathrm{O}_{2}(\mu \mathrm{mol} / \mathrm{L})$ & $16.33 \pm 0.86$ & $17.22 \pm 0.891$ & $15.65 \pm 0.89$ \\
$\mathrm{MDA}(\mu \mathrm{mol} / \mathrm{L})$ & $0.359 \pm 0.020$ & $0.425 \pm 0.018$ & $0.382 \pm 0.020$ \\
$\mathrm{FRAP}(\mu \mathrm{mol} / \mathrm{L})$ & $1492.81 \pm 65.34$ & $1661.14 \pm 68.20$ & $1466.81 \pm 56.65$ \\
\hline
\end{tabular}

Data is expressed as mean \pm SEM. $\mathrm{n}=30$

AOPP: advanced oxidation protein product; $\mathrm{H}_{2} \mathrm{O}_{2}$ : hydrogen peroxide and uric acid; MDA: malondialdehyde; FRAP: ferric-reducing antioxidant power

Levels of AOPP, $\mathrm{H}_{2} \mathrm{O}_{2}$, MDA and FRAP in normal, cancer and diabetic patients are depicted in Table 3. There were no significant differences in the parameters tested between male and female patients (results not shown). Level of AOPP was significantly higher in breast $(135.62 \pm 5.80 \mu \mathrm{mol} / \mathrm{L}, p<$ $0.05)$, colorectal $(173.06 \pm 12.14 \mu \mathrm{mol} / \mathrm{L}, p<0.001)$ and other types of cancers $(166.04 \pm 9.06 \mu \mathrm{mol} / \mathrm{L}, p<0.001)$ compared to diabetes $(111.25 \pm 5.39 \mu \mathrm{mol} / \mathrm{L})$. Other parameters did not show any significant differences when compared with diabetes.

Table 1: Demographic data

\begin{tabular}{|c|c|c|c|c|c|c|c|}
\hline & Normal & Breast cancer & CRC & $\begin{array}{l}\text { Other types } \\
\text { of cancers }\end{array}$ & Diabetes & $\begin{array}{c}\text { Breast } \\
\text { cancer * }\end{array}$ & CRC * \\
\hline $\mathrm{n}$ & 85 & 95 & 45 & 64 & 140 & 46 & 28 \\
\hline Age (years) & $57 \pm 11$ & $56 \pm 12$ & $60 \pm 11$ & $57 \pm 13$ & $55 \pm 12$ & $54 \pm 9$ & $61 \pm 12$ \\
\hline \multicolumn{8}{|l|}{ Gender: } \\
\hline a) Male & a) 33 & a) Nil & a) 28 & a) 42 & a) 65 & a) Nil & a) 19 \\
\hline b) Female & b) 52 & b) 95 & b) 17 & b) 22 & b) 75 & b) 46 & b) 9 \\
\hline Weight (kg) & $58 \pm 12$ & $58 \pm 11$ & $56 \pm 14$ & $61 \pm 14$ & $67 \pm 15$ & $56 \pm 11$ & $55 \pm 10$ \\
\hline Height (cm) & $158 \pm 13$ & $154 \pm 5$ & $160 \pm 9$ & $171 \pm 7$ & $158 \pm 8$ & $155 \pm 5$ & $158 \pm 8$ \\
\hline
\end{tabular}

Data is expressed as mean $\pm \mathrm{SD} . *$ Refers to cancer subjects recruited for comparison of cancer stages, CRC: colorectal cancer.

Table 3: Urinary oxidative indices in normal, cancer and diabetic patients

\begin{tabular}{lrcccc}
\hline $\begin{array}{l}\text { Sample } \\
\text { group }\end{array}$ & $\mathbf{n}$ & $\begin{array}{c}\text { AOPP } \\
(\boldsymbol{\mu} \mathbf{m o l} / \mathbf{L})\end{array}$ & $\begin{array}{c}\text { MDA } \\
(\boldsymbol{\mu m o l} / \mathbf{L})\end{array}$ & $\begin{array}{c}\mathbf{H}_{\mathbf{2}} \mathbf{O}_{\mathbf{2}} \\
(\boldsymbol{\mu m o l} / \mathbf{L})\end{array}$ \\
\hline Control & 85 & $105.87 \pm 4.44$ & $0.571 \pm 0.031$ & $17.10 \pm 0.89$ & $\begin{array}{c}\text { FRAP } \\
(\boldsymbol{\mu m o l} / \mathbf{L})\end{array}$ \\
Breast cancer & 90 & $135.62 \pm 5.80^{* * * \#}$ & $0.635 \pm 0.046$ & $17.30 \pm 1.26$ & $1350.88 \pm 94.99^{* * *}$ \\
CRC & 45 & $173.06 \pm 12.14^{* * *} a$ & $0.758 \pm 0.071^{* *}$ & $24.07 \pm 2.30^{* *}$ & $1530.66 \pm 98.23^{* *}$ \\
Other types of cancers & 64 & $166.04 \pm 9.06^{* * * \# \#}$ & $0.765 \pm 0.068^{* *}$ & $20.71 \pm 1.76$ & $1309.44 \pm 92.01^{* * *}$ \\
Diabetes-overall & 140 & $111.25 \pm 5.39$ & $0.781 \pm 0.045^{* *}$ & $22.07 \pm 1.53^{*}$ & $1491.34 \pm 60.03^{* * *}$ \\
Diabetes with hypertension & 96 & $112.15 \pm 6.74$ & $0.741 \pm 0.047$ & $21.95 \pm 1.852$ & $1518.73 \pm 76.22$ \\
Diabetes without hypertension & 44 & $109.27 \pm 8.92$ & $0.883 \pm 0.100$ & $22.32 \pm 2.717$ & $1431.58 \pm 94.57$ \\
\hline
\end{tabular}

Data is expressed as mean \pm SEM. ${ }^{*} p<0.05,{ }^{* *} p<0.01,{ }^{* * *} p<0.001$ : comparison against control. \# $p<0.05$; \#\#\# $p<0.001$ : comparison between various cancer types and diabetes; ${ }^{a} p<0.05$ : comparison between breast cancer and CRC; ${ }^{b} p<0.05$ : comparison between breast cancer and other types of cancers. 
Tables 4 and 5 depict the levels of oxidative indices according to different cancer stages in breast and colorectal cancer patients, respectively. Levels of the oxidative parameters in breast cancer patients did not exhibit any significant difference when compared according to various cancer stages. In colorectal cancer patients, urinary AOPP level was significantly higher in cancer stage IV $(212.2 \pm 31.42 \mu \mathrm{mol} / \mathrm{L}, p<$ $0.05)$ compared to stage III $(143 \pm 10.12 \mu \mathrm{mol} / \mathrm{L})$, whereas, urinary FRAP level of colorectal cancer patients at stage IV was significantly lower $(934.9 \pm 79.9 \mu \mathrm{mol} / \mathrm{L}, p<0.05) \mathrm{com}-$ pared to the patients at stage III $(1455.0 \pm 131.3 \mu \mathrm{mol} / \mathrm{L})$.

Table 4: Oxidative indices according to different stages of breast cancer

\begin{tabular}{lccc}
\hline Cancer stages & Stage I & Stage II & Stage III \\
\hline $\mathrm{n}$ & 6 & 26 & 14 \\
$\mathrm{AOPP}(\mu \mathrm{mol} / \mathrm{L})$ & $146.5 \pm 53.96$ & $148.8 \pm 17.88$ & $206.6 \pm 24.45$ \\
$\mathrm{H}_{2} \mathrm{O}_{2}(\mu \mathrm{mol} / \mathrm{L})$ & $18.96 \pm 1.79$ & $23.07 \pm 1.31$ & $25.12 \pm 1.66$ \\
$\mathrm{MDA}(\mu \mathrm{mol} / \mathrm{L})$ & $0.354 \pm 0.050$ & $0.3615 \pm 0.039$ & $0.4324 \pm 0.053$ \\
$\mathrm{FRAP}(\mu \mathrm{mol} / \mathrm{L})$ & $988.9 .0 \pm 124.4$ & $1204.0 \pm 111.5$ & $1196.0 \pm 124.0$ \\
\hline
\end{tabular}

Data is expressed as mean \pm SEM; AOPP: advanced oxidation protein product; $\mathrm{H}_{2} \mathrm{O}_{2}$ : hydrogen peroxide and uric acid; MDA: malondialdehyde; FRAP: ferric-reducing antioxidant power

Table 5: Oxidative indices according to different stages of colorectal cancer

\begin{tabular}{lccl}
\hline Cancer stages & Stage II & Stage III & \multicolumn{1}{c}{ Stage IV } \\
\hline $\mathrm{n}$ & 5 & 14 & 9 \\
$\mathrm{AOPP}(\mu \mathrm{mol} / \mathrm{L})$ & $142.5 \pm 20.25$ & $143 \pm 10.12$ & $212.2 \pm 31.42^{*}$ \\
$\mathrm{H}_{2} \mathrm{O}_{2}(\mu \mathrm{mol} / \mathrm{L})$ & $15.06 \pm 1.19$ & $16.5 \pm 1.08$ & $15.91 \pm 1.69$ \\
$\mathrm{MDA}(\mu \mathrm{mol} / \mathrm{L})$ & $0.365 \pm 0.063$ & $0.429 \pm 0.030$ & $0.411 \pm 0.031$ \\
$\mathrm{FRAP}(\mu \mathrm{mol} / \mathrm{L})$ & $1470.0 \pm 264.4$ & $1455.0 \pm 131.3$ & $934.9 \pm 79.9^{*}$ \\
\hline
\end{tabular}

Data is expressed as mean $\pm \mathrm{SEM} . * p<0.05$ is comparison between stage III and stage IV (One-way ANOVA)

AOPP: advanced oxidation protein product; $\mathrm{H}_{2} \mathrm{O}_{2}$ : hydrogen peroxide and uric acid; MDA: malondialdehyde; FRAP: ferric-reducing antioxidant power

\section{DISCUSSION}

The inflammation present in tumour microenvironment involves leukocyte infiltration which will result in increased production of pro-inflammatory mediators, such as cytokines, and free radicals namely reactive oxygen and nitrogen species. These mediators will subsequently increase the expression of oncogenes and gene transcription factors such as NF- $\mathrm{KB}$ (nuclear factor $\mathrm{\kappa B}$ ), and HIF-1 $\alpha$ (hypoxia-inducible factor $1 \alpha$ ) that are known to enhance tumour cell proliferation, invasion, angiogenesis, and eventually cause chemoresistance as well as radioresistance (15).

In the current study, factors that may affect the levels of urinary metabolites due to free radical damage was assessed using four main oxidative indices namely: AOPP, $\mathrm{H}_{2} \mathrm{O}_{2}$, MDA and FRAP. Advanced oxidation protein product is a wellknown indicator for oxidative protein damage caused by chlorinated oxidants such as chloramines and hypochlorous acid (12). The MDA level indicates the overall lipid peroxidation (damage to lipid) which is a well-known process of cellular injury in human, and is used as an indicator of oxidative stress in cells and tissues (16). Hydrogen peroxide and uric acid is an oxidizing agent that can simply be converted into $\cdot \mathrm{OH}$ when exposed to ultraviolet ray or ferrous ion (17). Urinary $\mathrm{H}_{2} \mathrm{O}_{2}$ has been previously used as an oxidative stress biomarker in malignancy (8). Ferric-reducing antioxidant power level indicates the total amount of non-enzymatic antioxidants such as lipid-soluble Vitamins namely Vitamin E and Vitamin A or provitamin A (beta-carotene), and the water-soluble Vitamin $\mathrm{C}$, uric acid, bilirubin and glutathione (14).

The data depicted in Table 2 shows that different sample collection periods especially during day-time do not significantly influence the levels of parameters assayed. Nevertheless, the mild rise and fall of the biomarkers assayed after food intake implicate that sample collection before a meal is preferable. Food intake may alter the urine sample $\mathrm{pH}$ which is known to be an important factor in identifying several renal and metabolic disorders (18).

Apart from cancer, oxidative stress has also been implicated in the pathophysiology of diabetes and hypertension (19, 20). Therefore, the four oxidative parameters were also measured in diabetic patients with and without hypertension for comparison (Table 3). Diabetes and hypertension are the two common coexisting diseases which have increasing prevalence worldwide and in Malaysia. A study carried out on 517 patients with Type 2 diabetes mellitus in Melaka, Malaysia reported that $67.7 \%$ of them were associated with hypertension (21). Diabetic patients with hypertension have high-risk of both macrovascular and microvascular complications which will eventually lead to cardiovascular disease (22). Pro-oxidant generation was reported to be increased while antioxidant defense decreased in renal tissues of diabetic rats with hypertension (23). In contrast, our results indicate that there is no significant difference in the urinary oxidative biomarkers between diabetic patients with and without hypertension (Table 3 ). Thus, we have classified both the hypertensive and non-hypertensive diabetic patients within the same group as 'diabetes - overall' in Table 3. The lack of significant difference between the hypertensive and non-hypertensive diabetic groups could be possibly due to the different types of antihypertensive drugs consumed by the diabetic patients which may play a role in lowering the oxidative stress level. The antihypertensive drug, nebivolol was reported to significantly attenuate the oxidative stress in hypertensive patients (24).

Table 3 shows that the levels of $\mathrm{H}_{2} \mathrm{O}_{2}$ and MDA were significantly elevated but the FRAP level was decreased in the diabetic group compared to the normal group. This observation is in accordance with numerous findings which have shown that oxidative stress is one of the causative factors of diabetes (25). Although not significant, the level of AOPP in diabetic patients was slightly higher compared to the control subjects. Advanced oxidation protein product has been widely used as an indicator for ROS-induced protein damage in patients with renal disease, atherosclerosis and diabetes mellitus 
$(12,26,27)$. To date, there has been only one study which reported on the elevated levels of plasma AOPP in Malaysian diabetic patients with renal complications (28).

Besides this, there has been only a few sporadic studies which have reported on the elevated level of serum AOPP in cancer patients $(5,29,30)$. To the best of our knowledge, thus far, our previous study on the assessment of oxidative stress in breast and colorectal cancer patients is the only one which has reported on the urinary AOPP levels in cancer patients (10). In the present study, comparative analysis between cancer and diabetes groups (Table 3 ) shows that the levels of AOPP in patients with breast cancer, CRC as well as other types of cancers were significantly higher compared to the diabetic group. This observation suggests that protein damage in cancer patients is more intense compared to in diabetic patients. The elevated protein damage could also be due to the chemotherapy that leads to an increased breakdown of cellular material. Therefore, results from the current study conform to our previous findings that AOPP could be used as a useful non-invasive biomarker for cancer.

Levels of all the parameters tested in breast cancer did not show any significant differences when compared among the different cancer stages (Table 4). However, the levels of AOPP, $\mathrm{H}_{2} \mathrm{O}_{2}$ and MDA in breast cancer patients at stage III were relatively higher compared to stage I whereas in CRC, the level of AOPP was significantly increased in patients at stage IV compared to stage III (Table 5). These observations concur with the hypothesis that free radical induced protein damage correlates with the severity of cancer which is commonly reflected by the cancer stages. Our results conform to a previous study which showed that patients with advanced breast cancer (stages III and IV) were found to have higher serum advanced glycation end products and AOPP levels compared to patients at stages I and II (5). Besides this, Khanzode et al (31) have observed that MDA level in breast cancer patients had increased gradually from stage I-to-stage IV as compared to the control group.

Ferric-reducing antioxidant power level in breast cancer patients increased from stage I-to-stage II and decreased at stage III but results were not significant (Table 4). In CRC, FRAP level mildly decreased in stage III compared to stage II and continued to significantly decrease at stage IV compared to stage III (Table 5). In general, the decreased level of FRAP especially in CRC leads to the speculation that the non-enzymatic antioxidants may be sequestrated by tumour cells to ease tumour progression or carcinogenesis. Concurring to our findings, plasma ascorbic acid levels in breast cancer were reported to be prominently decreased at stage III and stage IV compared to stage II (31).

\section{CONCLUSION}

The levels of oxidative stress in breast and colorectal cancer patients which generally increased with the cancer stage, confirm the fact that cancer progression correlates with high oxidative damage. The comparison in the levels of urinary oxidative indices between cancer and diabetes (with and without hypertension) indicate that urinary AOPP may serve as a good non-invasive oxidative biomarker for cancers namely breast and colorectal cancers.

\section{REFERENCES}

1. Stewart BW, Wild CP, eds. World Cancer Report 2014. Lyon, France: International Agency for Research on Cancer (IARC) Nonserial Publication; 2014.

2. Zainal Ariffin O, Nor Saleha IT. National Cancer Registry Report 2007Malaysia Cancer Statistics-Data and Figure: Ministry of Health, Malaysia; 2011.

3. Halliwell B. Free radicals, antioxidants, and human disease: curiosity, cause, or consequence? Lancet 1994; 344: 721-4.

4. Valko M, Rhodes CJ, Moncol J, Izakovic M, Mazur M. Free radicals, metals and antioxidants in oxidative stress-induced cancer. Chem Biol Interact 2006; 160: 1-40.

5. Tesarova P, Kalousova M, Trnkova B, Soukupova J, Argalasova S, Mestek $\mathrm{O}$ et al. Carbonyl and oxidative stress in patients with breast cancer - is there a relation to the stage of the disease? Neoplasma 2007; 54: 219-24.

6. Jansen E, Beekhof P, Viezeliene D, Muzakova V, Skalicky J. Long-term stability of cancer biomarkers in human serum: biomarkers of oxidative stress and redox status, homocysteine, CRP and the enzymes ALT and GGT. Biomark Med 2015; 9: 425-32.

7. Gokul S, Patil VS, Jailkhani R, Hallikeri K, Kattappagari KK. Oxidantantioxidant status in blood and tumor tissue of oral squamous cell carcinoma patients. Oral Dis 2010; 6: 29-33.

8. Banerjee D, Madhusoodanan UK, Nayak S, Jacob J. Urinary hydrogen peroxide: a probable marker of oxidative stress in malignancy. Clin Chim Acta 2003; 334: 205-09.

9. Almadori G, Bussu F, Galli J, Limongelli A, Persichilli S, Zappacosta B et al. Salivary glutathione and uric acid levels in patients with head and neck squamous cell carcinoma. Head Neck 2007; 29: 648-54.

10. Chandramathi S, Suresh K, Anita ZB, Kuppusamy UR. Comparative assessment of urinary oxidative indices in breast and colorectal cancer patients. J Cancer Res Clin Oncol 2009; 135: 319-23.

11. Shioji I. [Oxidative stress related diseases and biopyrrins]. Rinsho Byori 2005; 53: 155-9. (in Japanese)

12. Witko-Sarsat V, Friedlander M, Nguyen Khoa T, Capeillere-Blandin C, Nguyen AT, Canteloup S et al. Advanced oxidation protein products as novel mediators of inflammation and monocyte activation in chronic renal failure. J Immunol 1998; 161: 2524-32.

13. Kuppusamy UR, Indran M, Rokiah P. Glycaemic control in relation to xanthine oxidase and antioxidant indices in Malaysian Type 2 diabetes patients. Diabet Med 2005; 22: 1343-6.

14. Benzie IF, Strain JJ. The ferric reducing ability of plasma (FRAP) as a measure of "antioxidant power": the FRAP assay. Anal Biochem 1996; 239: 70-6.

15. Vendramini-Costa DB, Carvalho JE. Molecular link mechanisms between inflammation and cancer. Curr Pharm Des 2012; 18: 3831-52.

16. Cejas P, Casado E, Belda-Iniesta C, De Castro J, Espinosa E, Redondo A et al. Implications of oxidative stress and cell membrane lipid peroxidation in human cancer (Spain). Cancer Causes Control 2004; 15: 707-19.

17. Halliwell B, Clement MV, Long LH. Hydrogen peroxide in the human body. FEBS Lett 2000; 486: 10-3.

18. Skinner R, Cole M, Pearson AD, Coulthard MG, Craft AW. Specificity of $\mathrm{pH}$ and osmolality of early morning urine sample in assessing distal renal tubular function in children: results in healthy children. BMJ 1996; 312: $1337-8$.

19. Schaffer SW, Jong CJ, Mozaffari M. Role of oxidative stress in diabetesmediated vascular dysfunction: Unifying hypothesis of diabetes revisited. Vascul Pharmacol 2012; 57: 139-49.

20. Virdis A, Duranti E, Taddei S. Oxidative stress and vascular damage in hypertension: Role of angiotensin II. Int J Hypertens 2011; Article ID 916310: 7 pages. 
21. Chan GC. Type 2 diabetes mellitus with hypertension at primary healthcare level in Malaysia: are they managed according to guidelines? Singapore Med J 2005; 46: 127-31.

22. Arauz-Pacheco C, Parrott MA, Raskin P. Treatment of hypertension in adults with diabetes. Diabetes Care 2003; 26: 80-2.

23. Biswas SK, Peixoto EB, Souza DS, de Faria JB. Hypertension increases pro-oxidant generation and decreases antioxidant defense in the kidney in early diabetes. Am J Nephrol 2008; 28: 133-42.

24. Celik T, Iyisoy A, Kursaklioglu H, Kardesoglu E, Kilic S, Turhan H et al. Comparative effects of nebivolol and metoprolol on oxidative stress, insulin resistance, plasma adiponectin and soluble P-selectin levels in hypertensive patients. J Hypertens 2006; 24: 591-6.

25. Kuyvenhoven JP, Meinders AE. Oxidative stress and diabetes mellitus: Pathogenesis of long-term complications. Eur J Intern Med 1999; 10: 919.

26. Kalousova M, Skrha J, Zima T. Advanced glycation end-products and advanced oxidation protein products in patients with diabetes mellitus. Physiol Res 2002; 51: 597-604.
27. Descamps-Latscha B, Witko-Sarsat V, Nguyen-Khoa T, Nguyen AT, Gausson V, Mothu $\mathrm{N}$ et al. Advanced oxidation protein products as risk factors for atherosclerotic cardiovascular events in nondiabetic predialysis patients. Am J Kidney Dis 2005; 45: 39-47.

28. Kuppusamy UR, Indran M, Ahmad T, Wong SW, Tan SY, Mahmood AA. Comparison of oxidative damage in Malaysian end-stage renal disease patients with or without non-insulin-dependent diabetes mellitus. Clin Chim Acta 2005; 351: 197-201

29. Kosova F, Cetin B, Akinci M, Aslan S, Ari Z, Sepici A et al. Advanced oxidation protein products, ferrous oxidation in xylenol orange, and malondialdehyde levels in thyroid cancer. Ann Surg Oncol 2007; 14: 2616-20.

30. Avinash SS, Anitha M, Vinodchandran, Rao GM, Sudha K, Shetty BV. Advanced oxidation protein products and total antioxidant activity in colorectal carcinoma. Indian J Physiol Pharmacol 2009; 53: 370-4.

31. Khanzode SS, Muddeshwar MG, Khanzode SD, Dakhale GN. Antioxidant enzymes and lipid peroxidation in different stages of breast cancer. Free Radic Res 2004; 38: 81-5. 